UDC 633.15-251(437.6)"2014/2016"

Original research paper

doi: 10.5937/AASer1947051T

Acta Agriculturae Serbica, Vol. XXIV, 47(2019); 51-59

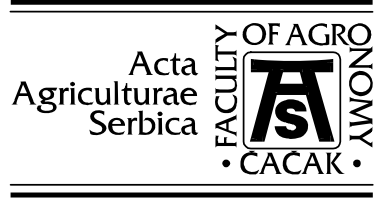

\title{
The impact of different weed control methods on weed infestation in maize (Zea mays $\mathrm{L}$.)
}

\author{
Štefan Týr ${ }^{1}$ \\ ${ }^{1}$ Slovak University of Agriculture in Nitra, Faculty of Agrobiology and Food \\ Resources, Department of Sustainable Agriculture and Herbology, Tr. Andreja \\ Hlinku 2, 94976 Nitra, Slovak Republic \\ Corresponding author: Stefan.Tyr@uniag.sk
}

\begin{abstract}
The aim of the study was to evaluate the occurrence and development of weed species as actual weed infestation of maize in sustainable farming systems. The specific goals of the study were to assess the dynamics of occurrence of each weed species in integrated and ecological farming systems, and to evaluate the impact of farming system, manure or fertiliser application and year on the presence of weeds in maize stands from 2014 to 2016. In the integrated non-fertilised maize cropping system, the following weed species were dominant in the spring: Amaranthus retroflexus, Cirsium arvense, Chenopodium album, Persicaria maculosa and Echinochloa crus galli. In the integrated fertilised maize cropping system, the following weed species were dominant in the spring: Amaranthus retroflexus, Chenopodium album, Cirsium arvense, Echinochloa crus galli, Convolvulus arvensis and Cardaria draba. In the integrated maize cropping system, Silybum marianum occurred as a weed at medium density. Silybum marianum was cultivated two years ago and its seeds were in a state of dormancy for that time. The efficacy of the herbicide treatment in the integrated system was excellent. In the ecological non-fertilised maize cropping system, the following weed species were dominant in the spring: Amaranthus retroflexus, Chenopodium album, Cirsium arvense, Avena fatua and Sonchus oleraceus. In the ecological fertilised maize cropping system, the following weed species were dominant in the spring: Amaranthus retroflexus, Chenopodium album, Echinochloa crus galli, Avena fatua, Persicaria maculosa, Cirsium arvense and Convolvulus arvensis. In the ecological farming system, due to insufficient mechanical weed control, a higher level of maize infestation with Avena fatua as an annual grass weed species was detected.
\end{abstract}

Received 31 August 2018 Accepted 20 August 2019 
Keywords: weeds, farming system, maize.

\section{Introduction}

Weed infestation is one of the critical factors limiting the productivity of maize under field conditions (Saleem et al., 2015). Pannacci (2016) observed that weed control has a major effect on the success of maize growth, because the competition ability of maize is relatively low at early crop growth stages. Weed control in maize largely depends on chemical methods. A high input of herbicides results in environmental pollution, risks of residue carry-over and the development of weed resistance (Pannacci, 2016).

In Hossard et al. (2015), organic and low-input systems are proposed as ways to reduce the environmental impacts of agriculture. Previous studies have shown that yields of organic systems can be $\sim 19$ to $25 \%$ lower than conventional systems. An intermediary, low-input system could be less damaging for the environment than conventional systems, while reducing yield losses in comparison with organic systems. Pesticide use was greatly reduced in low-input systems as compared with conventional ones by $50 \%$ for maize.

The results of Pannacci and Tei (2014) showed that it is possible to halve the amount of herbicides with no loss in weed control efficacy and crop yield, by combining chemical weed control in the row with inter-row hoeing. If no herbicides are used (e.g. in organic farming), mechanical methods can ensure a good selectivity to the crops but they need to be carefully chosen, to avoid losses in weed control ability and crop yield.

In a review by Mhlanga et al. (2016), weeds are a major constraint to crop production, and are responsible for considerable yield losses in maize production systems throughout the world. Herbicides are widely used for weed control in maize production systems, but can have negative environmental consequences. Researchers have evaluated the use of crop competition and suppression to manage weeds in various crop combinations, including maize-based systems. Crop competition in maize may involve techniques such as reduced row spacing, increased planting density, and the use of competitive cultivars that exhibit weed suppressive potential. The scientific literature has revealed the considerable value of using crop competition in integrated weed management programmes. Research has demonstrated that narrowing row spacing to half the standard distance reduced weed biomass by $39-68 \%$, depending on weed species.

In experiments of Tursun et al. (2016), knowledge of the crop-weed competition period is vital for designing effective weed management strategies in crop production systems. Field studies were conducted in 2013 and 2014 to determine the critical period for weed control in three corn (Zea mays L.) types (field corn, popcorn, and sweet corn). A parameter model described the relationship between relative crop yield and increasing duration of weed interference and length of weed-free periods. The relative yield of corn was 
influenced by duration of weed - infested or weed-free period, regardless of corn types. Increasing periods of weed interference significantly reduced corn yields in both years. The practical implication of this study is that weed management should be initiated around V1 stage and maintained weed-free up to V12 stage in all corn types to prevent yield losses greater than 5\%. These findings help corn producers improve the cost effectiveness and efficacy of their weed management programmes.

In Vasileidais et al. (2015) the development and implementation of integrated weed management strategies that provide good weed control while reducing dependence on herbicides, and preferably without having side effects on the overall system economic performance, is still a challenge that has to be met. In 2011 and 2012, nine on-farm experiments (i.e. real field conditions on commercial farms, with natural weed flora) were conducted in three important European maize producing regions-countries, which represent the range of climatic and edaphic conditions in Europe, to evaluate the efficacy of different locally selected integrated weed management tools for direct weed control in maize vs. the conventional approach (CON) followed by the farms. The integrated weed management tools tested were: early post-emergence herbicide band application combined with hoeing followed by a second hoeing in Southern Germany, early post-emergence herbicide broadcast application when indicated by a predictive model of weed emergence after performing one scouting in the field to supply data for the model, followed by hoeing in Northern Italy, and tine harrowing at the $2 \mathrm{nd}-3 \mathrm{rd}$ leaf stage of maize and a low dose of a post-emergence herbicide in Slovenia. Results showed that the integrated weed management tools tested in the different countries: provided sufficient weed control without any significant differences in yields, greatly reduced maize reliance on herbicides, and integrated weed management implementation was economically sustainable as no significant differences in gross margin were observed in any country compared to the conventional approach. Similar results were obtained by Hussain et al. (2017).

Verschwele et al. (2016) found that, however, considering the variation of the residual weed density in this study, it is evident that the integrated weed management strategy may result in high weed seed production before harvest and consequently in weed problems in the succeeding crops. Also, on a larger scale (e.g. farms growing more than 30 ha maize), the use of IWM as tested here is limited because of the low area performance and the high risk of unfavourable weather and soil conditions. On the other hand, the findings also demonstrate a strong need for further technical improvements in order to achieve a broad and cost-efficient use of integrated weed management tools in Europe.

Stepanović et al. (2016) suggest that flaming and cultivation applied separately or combined in a single operation, as a single trip across the field, have a potential to be used for weed control in organic maize production systems. 


\section{Material and methods}

Field experiments were conducted in 2014, 2015 and 2016 at the Experimental Base of the Slovak University of Agriculture in Nitra, locality Dolná Malanta.

The aim of the study was to evaluate the occurrence and development of weed species as actual weed infestation of maize in sustainable farming systems. The specific goals of this study were to assess the dynamics of occurrence of each weed species in integrated and ecological farming systems, and to evaluate the impact of farming system, manure and fertiliser use and year on the presence of weeds in maize stands from 2014 to 2016.

Field trials were realised in two farming systems: an integrated system and an ecological farming system, both involving non-fertilised and fertilised treatments. In the integrated farming system, herbicides were used for weed control at the stage of 4 to 5 leaves of maize according to actual weed infestation. The crop was fertilised with industrial fertilisers and manure in order to achieve the planned crop yields. Manure was applied every year in the autumn. In the ecological farming system, hoeing was used to control weeds in the spring at the same date as chemical weed control in the integrated farming system. For fertilization, only manure was used, by means of the balance method in the autumn.

The additional goals of the study were to assess the effectiveness of weed control methods and propose regulatory measures undertaken against weeds, as well as to evaluate the impact of weeds on maize stands from 2014 till 2016.

In experimental plots in 2014-2016, the soil was prepared in a conventional manner to create favourable conditions for sowing, treatment and emergence of the maize crop. After maize emergence, the emergence of weeds was detected in a $1 \mathrm{~m}^{2}$ area in the management systems used. After complete weed emergence (for a dense inter-row crop in the third leaf stage of the Fekees scale), weed infestation was calculated using the method for measuring the number of weed species per unit area $\left(1 \mathrm{~m}^{2}\right)$.

This method is used to count all weeds, regardless of the degree of development, and identify the species present. This procedure is performed in fertilised and non-fertilised treatments in four replications.

We determined:

1. the state of the crop and weeds in spring (ecological system) and before spraying herbicides in the spring (integrated system);

2. the state of the crop and weeds in the spring after spraying herbicides (integrated system);

3. the state of the crop and weeds before harvesting the crop using the combined method (arithmetic - weight). Weed infestation of crops was evaluated according to procedure described in Hosnedl et al. (1979) in Týr and Vereš (2012). The Hosnedl et al. (1979) procedure recommends weed steps S1 - S6, 
but in the realisation of experiments we used a modified scale S1 - S4, with respect to the functionality described in Týr (1997) (cit., in Týr and Vereš, 2012).

\section{Results and Discussions}

In 2014, weather conditions (temperature and precipitation) were favourable for good growth, competitive ability and canopy closing of the maize stand. The number of weeds in non-fertilised soils was 43.81 per $\mathrm{m}^{2}$, in contrast to the ecological fertilised system, where the number of weeds decreased to 42.25 per $\mathrm{m}^{2}$. The number of weeds in the integrated system with unharmed weeds was 16.00 per $\mathrm{m}^{2}$, unlike the integrated fertilised system, where the incidence of weeds was 37.5 per $\mathrm{m} 2$. In 2015, weather conditions (temperature and precipitation) were not suitable for good growth and competitive ability and canopy closing of the maize stand. The number of weeds in the spring of 2015 in non-fertilised soils was 22.5 per $\mathrm{m}^{2}$, in contrast to the ecological fertilised system, where the incidence of weeds increased to 28.25 per $\mathrm{m}^{2}$. The number of weeds in the integrated non-fertilised system was 19.25 per $\mathrm{m}^{2}$, unlike the integrated fertilised system, where the incidence of weeds increased to 28.5 per $\mathrm{m}^{2}$.

On the basis of the results obtained before the 2014 harvest, the number of weeds in non-fertilised soils was 7.75 per $\mathrm{m}^{2}$, unlike the ecological fertilised system, where the incidence of weeds increased to 14.00 per $\mathrm{m}^{2}$. The number of weeds before harvest in the integrated cultivation system was not detected, the incidence of weeds was 2 per $\mathrm{m}^{2}$, compared with the integrated fertilised system, where the prevalence of weeds increased to 2.25 per $\mathrm{m}^{2}$. In 2015 , the number of weeds in non-fertilised soils was 9.5 per $\mathrm{m}^{2}$, in contrast to the organic fertilised system, where the incidence increased to 10.75 per $\mathrm{m}^{2}$. The number of weeds before harvest in the integrated cultivated system was not detected, weeds were 2.5 per $\mathrm{m}^{2}$, unlike the integrated fertilised system, where the number of weeds declined to 2.25 per $\mathrm{m}^{2}$.

In 2014-2016, the most important weeds before herbicide application in the spring in the integrated non-fertilised system were: Amaranthus retroflexus, Cirsium arvense, Chenopodium album, Persicaria maculosa, and Echinochloa crus galli, whereas Stellaria media and Lamium amplexicuale were less dominant. Before herbicide application in the spring ,the most important weed species in the integrated fertilised system were: Amaranthus retroflexus, Chenopodium album, Cirsium arvense, Echinochloa crus galli, Convolvulus arvensis and Cardaria draba. Less dominant species were: Persicaria maculosa, Portulaca oleracea, Chenopodium hybridum, and Silybum marianum.

In spite of perennial weed species, annual weeds occurred each year in the maize stands. They significantly influenced the actual weed infestation of maize. The occurrence of these weed species is typical of maize stands. Higher germination of these weed species was promoted by soil cultivation and weather 
conditions after sowing. Therefore, there was higher actual weed infestation in the spring before herbicide application (Table 1).

Table 1. Actual weed infestation of maize stands in spring in 2014-2016 (number of weeds per square $\mathrm{m}$ )

\begin{tabular}{|l|l|l|l|l|}
\hline Year & IS NF & IS F & ES NF & ES F \\
\hline 2014 & $16.25 \mathrm{a}$ & $37.75 \mathrm{ef}$ & $43.25 \mathrm{e}$ & $42.50 \mathrm{e}$ \\
\hline 2015 & $19.25 \mathrm{ab}$ & $28.75 \mathrm{~cd}$ & $22.25 \mathrm{abc}$ & $28.75 \mathrm{~cd}$ \\
\hline 2016 & $24.50 \mathrm{bc}$ & $33.25 \mathrm{de}$ & $44.75 \mathrm{e}$ & $43.75 \mathrm{e}$ \\
\hline Average & 20.00 & 33.25 & 36.75 & 38.33 \\
\hline
\end{tabular}

IS - integrated farming system; ES - ecological farming system; NF - non-fertilised; F - fertilised; LSD test $\mathrm{P}=0.05$

The occurrence and amount of weed species in the maize stands were rapidly reduced after the postemergence application of herbicide in the integrated farming system (Table 2). The effect of weed control was the same in both fertilised and non-fertilised treatments.

Table 2. Actual weed infestation before harvest of maize in 2014-2016 (number of species per square $\mathrm{m}$ )

\begin{tabular}{|l|l|l|l|l|}
\hline Year & IS NF & IS F & ES NF & ES F \\
\hline 2014 & $1.75 \mathrm{a}$ & $2.00 \mathrm{a}$ & $8.00 \mathrm{~b}$ & $13.75 \mathrm{~d}$ \\
\hline 2015 & $2.25 \mathrm{a}$ & $2.00 \mathrm{a}$ & $9.25 \mathrm{bc}$ & $10.25 \mathrm{bc}$ \\
\hline 2016 & $2.75 \mathrm{a}$ & $2.50 \mathrm{a}$ & $9.75 \mathrm{bc}$ & $11.75 \mathrm{~cd}$ \\
\hline Average & 2.25 & 2.17 & 9.00 & 11.92 \\
\hline
\end{tabular}

IS - integrated farming system; ES - ecological farming system; NF - non-fertilised; $\mathrm{F}$ - fertilised; LSD test $\mathrm{P}=0.05$

In 2014-2016, the most important weed species in the ecological nonfertilised system in the spring before mechanical weed control were: Amaranthus retroflexus, Chenopodium album, Cirsium arvense, Avena fatua and Sonchus oleraceus. Less dominant species were: Echinochloa crus galli and Persicaria maculosa. In the ecological fertilised system, in the spring, the following weed species were dominant: Amaranthus retroflexus, Chenopodium album, Echinochloa crus galli, Avena fatua, Persicaria maculosa, Cirsium arvense and Convolvulus arvensis, followed by the less dominant weeds Chenopodium hybridum, Sonchus oleraceus and Polygonum aviculare. Apart from perennial weed species, which dominated the maize stands, actual weed infestation was also influenced by the occurrence of annual weed species in all years. The occurrence (germination) of all weed species was promoted by favourable weather conditions and soil cultivation method (Table 1). After mechanical weed control, inter-rows contained significantly more weeds in fertilised than in non- 
fertilised treatments. Inter-row mechanical weed control was insufficient and therefore all weeds in the inter-row spacing were present in the maize stand till harvest (Table 2). Mechanical weed control had a positive effect on the spread and reproduction of perennial weed species such as Convolvulus arvensis, Cirsium arvense and Cardaria draba. If all perennial weeds are to be satisfactorily controlled, mechanical weed control must be repeated several times (Table 2). Manure activates and increases soil biological activity as the result of the presence of readily available nutrients from manure, especially nitrogen (Šarić and Janjić, 2009). Amaranthus, Chenopodium, Persicaria, Echinochloa, Cirsium, Convolvulus and Cardaria are nitrophilic species.

Before these experiments, Týr (2013) obtained similar results from the same trial locality (Dolná Malanta). He found similar weed infestation in the integrated farming system: Amaranthus retroflexus, Chenopodium album, Cirsium arvense, Echinochloa crus galli, Persicaria maculosa, Portulaca oleracea, Chenopodium hybridum, Silybum marianum, Convolvulus arvensis and Cardaria draba. The chemical weed control used in the maize stands was successful, it managed to keep the field almost weed-free until the end of the vegetation period, which is possible in the integrated management system. The results of Weide et al. (2011) demonstrate the need to reduce the use of herbicides, mainly because herbicides can cause problems with respect to the quality of surface and groundwater. European and national regulations call for a reduction of this impact in such a way that efficiency is not compromised and there is no increased cost of pollution in general. Recently, the area of reduced soil cultivation has increased in Slovakia or the world. We have not implemented reduced cultivation in Slovakia, because sustainable land management systems cannot be applied (the irreplaceability of the importance of ploughing in the controlling deadness of weeds). Based on their research, it has been shown that reduced soil cultivation can be carried out on plots where there is no management of lasting weed species, without increasing the financial burden on herbicides.

As stressed by Radics and Glemitz (2009), weed management has made tremendous progress over the last 30 years. Technological developments in weed control are considered to be a key to raising crop yields by $20-25 \%$. Modern weed control has paved the way for simplifications in crop rotation technology as well as for increased yields in the ecological farming system.

\section{Conclusions}

In the integrated non-fertilised system of maize cropping, the following weed species were dominant in the spring: Amaranthus retroflexus, Cirsium arvense, Chenopodium album, Persicaria maculosa, and Echinochloa crus galli.

In the integrated fertilised system of maize cropping, the following weed species were dominant in the spring: Amaranthus retroflexus, Chenopodium 
album, Cirsium arvense, Echinochloa crus galli, Convolvulus arvensis and Cardaria draba.

In the integrated maize farming system, Silybum marianum was present at medium density. Silybum marianum was cultivated two years ago and its seeds were in a state of dormancy for that time. In the ecological non-fertilised system of maize cropping, the following weed species were dominant in the spring: Amaranthus retroflexus, Chenopodium album, Cirsium arvense, Avena fatua and Sonchus oleraceus.

In the ecological fertilised system of maize cropping, the following weed species were dominant in the spring: Amaranthus retroflexus, Chenopodium album, Echinochloa crus galli, Avena fatua, Persicaria maculosa, Cirsium arvense and Convolvulus arvensis.

In the ecological farming system, due to insufficient mechanical weed control, a higher level of maize stand infestation with Avena fatua as an annual grass weed species was detected.

The efficacy of the herbicide treatment in the integrated system was excellent.

\section{Acknowledgement}

The research was supported by VEGA č. 1/0513/12: "Research of agroecosystems to mitigate climate change, bioproducts production and improvement of nutrition and health parameters of humans".

\section{References}

Hossard L. Archer D.W., Bertrand M., Colnenne-David C., Debaeke P., Ernfors M., Jeuffroy M.H., Munier-Jolain N., Nilsson C., Sanford G. R., Snapp S.S., Jensen Erik.S., Makowski D. (2016): A Meta-Analysis of Maize and Wheat Yields in LowInput vs. Conventional and Organic Systems. Agronomy Journal, 108 (3): 1155-116.

Hosnedl V. et al. (1979): Metody biologicko-technologické kontrooly v rostlinné výrobě. MZVž ČSR, Praha:175 p.

Hussain M., Khan M.B., Shahzad M., Ullah A., Sher A., Sattar A. (2017): Influence of priming on emergence, weed infestation, growth and yield of wheat sown under different tillage practices. International Journal of Agriculture and Biology, 19: 367373.

Mhlanga B., Chauhan B.S., Thierfelder Ch. (2016): Weed management in maize using crop competition: A review. Crop Protection, 88: 28-36.

Pannacci E., Tei F. (2014): Effects of mechanical and chemical methods on weed control, weed seed rain and crop yield in maize, sunflower and soybean. Crop Protection, 64: 51-59.

Pannacci E. (2016): Optimization of foramsulfuron doses for post emergence weed control in maize (Zea mays L.). Spanish Journal of Agricultural Research, 14 (3):1-9. 
Radics L., Glemnitz M. (2009): Current weed management and the problem of the highly adaptive, cosmopolitan weed. 8th EWRS Workshop on Physical and Cultural Weed Control. Zaragoza, Spain, 9-11 March: p. 68.

Saleem M.T., Tanveer A., Abbas T. (2015): Weed control in forage maize with preemergence herbicides. Herbologia, 15 (2); 69-77.

Simić M., Spasojević I., Dragićević V., Brankov M., Dolijanović, Z. (2015): Combined application of crop rotation and low rates of herbicides for weed control in maize. Sixth International Scientific Agricultural Symposium "Agrosym 2015", Jahorina, Bosnia and Herzegovina, October 15-18. Book of Proceedings: 1433-1438.

Stepanović S., Datta A., Neilson B., Bruening Ch., Sharpio A., Gogos G., Knezević S.Z. (2016): Effectiveness of flame weeding and cultivation for weed control in organic maize. Biological Agriculture \& Horticulture, 32 (1): 47-62.

Tursun N., Datta A., Sakinmaz M., Kantarci Z., Knežević S., Chauhan B. (2016): The critical period for weed control in three corn (Zea mays L.) types. Crop Protection, 90: 59-65.

Týr Š., Vereš T. (2012): Top 10 of the most dangerous weed species in maize stands in the Slovak Republic in the years 2000-2010. Research Journal of Agricultural Science, 44 (2): 104-107.

Týr Š . (2013): Buriny a ich regulácia v porastoch hustosiatych obilnín. In Mohlo by byt' pestovanie obilnín ešte ziskovejšie?. Praha: Dow AgroSciences, 2013: 8-17.

Vasileidais V.P., Otto S., Von Dijk W., Urek G., Leskovšek R., Verschwele A., Furlan L., Sattin M. (2015): On-farm evaluation of integrated weed management tools for maize production in three different agro-environments in Europe: Agronomic efficacy, herbicide use reduction, and economic sustainability. Crop Protection, 63: 71-78.

Verschwele A., Vasileiadis V., Leskovsek R., Sattin M. (2016): On-farm investigations on integrated weed management in maize in three European countries. 27. Deutsche Arbeitsbesprechung über Fragen der Unkrautbiologie und - bekämpfung, 23-25. February in Braunschweig: 201-205.

Weide R.Y., Huiting H.F., Bleeker P.O., Reimens M.M. (2011): Pro's and con's of reduced tillage in maize with respect to weeds. 9th EWRS Workshop on Physical and Cultural Weed Control. Samsun, Turkey, 28-30 March. p. 13.

Šarić T., Janjić K. (2009): Istina i zablude o stajnjaku. Poljoprivreda i selo. Internet magazin. Available at: http://poljoprivredaiselo.com/2009/12/istina-i-zablude-ostajnjaku/ [Accessed 20 August 2017]. 